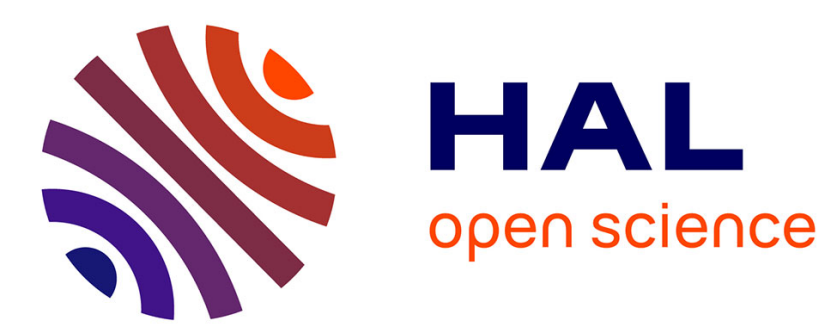

\title{
Substitution fluorine-oxygen in some ferroelectric compounds with oxygen octahedra
}

\author{
Jean Ravez, Paul Hagenmuller
}

\section{To cite this version:}

Jean Ravez, Paul Hagenmuller. Substitution fluorine-oxygen in some ferroelectric compounds with oxygen octahedra. Ferroelectrics, 1976, 14 (1), pp.669-670. 10.1080/00150197608236696 . hal00131556

\section{HAL Id: hal-00131556 \\ https://hal.science/hal-00131556}

Submitted on 15 Dec 2021

HAL is a multi-disciplinary open access archive for the deposit and dissemination of scientific research documents, whether they are published or not. The documents may come from teaching and research institutions in France or abroad, or from public or private research centers.
L'archive ouverte pluridisciplinaire HAL, est destinée au dépôt et à la diffusion de documents scientifiques de niveau recherche, publiés ou non, émanant des établissements d'enseignement et de recherche français ou étrangers, des laboratoires publics ou privés. 


\title{
SUBSTITUTION FLUORINE-OX YGEN IN SOME FERROELECTRIC COMPOUNDS WITH OXYGEN OCTAHEDRA
}

\author{
JEAN RAVEZ and PAUL HAGENMULLER \\ Laboratoire de Chimie du Solide du C.N.R.S., Université de Bordeaux I, 351 cours de la Libération, \\ 33405 Talence, France
}

\begin{abstract}
The substitution of oxygen by fluorine in some ferroelectric phases with a tetragonal tungsten bronze type structure has shown that the Curie temperature and the permittivity decrease with increasing fluorine content.
\end{abstract}

The $\mathrm{ABCNb}_{5} \mathrm{O}_{15}$ phases $(\mathrm{A}=\mathrm{Ca}, \mathrm{Sr}, \mathrm{Ba} ; \mathrm{B}=\mathrm{Ca}, \mathrm{Sr}$, $\mathrm{Ba} ; \mathrm{C}=\mathrm{Na}, \mathrm{K})$, with tetragonal tungsten bronze structure have ferroelectric properties. ${ }^{1-5}$ It seemed interesting to prepare derivated phases in which oxygen will be partially replaced by fluorine.

A certain number of $\mathrm{ACDNb}_{5} \mathrm{O}_{14} \mathrm{~F}$ compounds $(\mathrm{A}=\mathrm{Ca}, \mathrm{Sr}, \mathrm{Ba} ; \mathrm{C}=\mathrm{Na}, \mathrm{K} ; \mathrm{D}=\mathrm{Na}, \mathrm{K})$ have been obtained: $\mathrm{CaK}_{2} \mathrm{Nb}_{5} \mathrm{O}_{14} \mathrm{~F}, \mathrm{SrK}_{2} \mathrm{Nb}_{5} \mathrm{O}_{14} \mathrm{~F}, \mathrm{SrNaKNb}_{5}$ $\mathrm{O}_{14} \mathrm{~F}, \mathrm{BaNa}_{2} \mathrm{Nb}_{5} \mathrm{O}_{14} \mathrm{~F}, \mathrm{BaK}_{2} \mathrm{Nb}_{5} \mathrm{O}_{14} \mathrm{~F}$ and $\mathrm{BaNaKNb}_{5} \mathrm{O}_{14} \mathrm{~F}^{6}{ }^{6}$ However, it is possible to prepare phases with more fluorine, for example $\mathrm{K}_{3}\left(\mathrm{Nb}_{4} \mathrm{Ti}\right)$ $\mathrm{O}_{12} \mathrm{~F}_{3}$ and even $\mathrm{K}_{3} \mathrm{Fe}_{5} \mathrm{~F}_{15}$. $^{7}$

We propose to study the crystallographic and dielectric properties of the systems: $\mathrm{Sr}_{2} \mathrm{KNb}_{5} \mathrm{O}_{15}$ $\mathrm{SrK}_{2} \mathrm{Nb}_{5} \mathrm{O}_{14} \mathrm{~F}, \mathrm{Sr}_{2} \mathrm{KNb}_{5} \mathrm{O}_{15}-\mathrm{Sr}_{2} \mathrm{~K}\left(\mathrm{Nb}_{4} \mathrm{Ti}\right) \mathrm{O}_{14} \mathrm{~F}$ and $\mathrm{Ba}_{2} \mathrm{NaNb}_{5} \mathrm{O}_{15}-\mathrm{BaNa}_{2} \mathrm{Nb}_{5} \mathrm{O}_{14} \mathrm{~F}, \mathrm{Ba}_{2} \mathrm{NaNb}_{5} \mathrm{O}_{15}-$ $\mathrm{Ba}_{2} \mathrm{Na}\left(\mathrm{Nb}_{4} \mathrm{Ti}\right) \mathrm{O}_{14} \mathrm{~F}$. The electric neutrality is realized in two different ways. This is to make sure that the obtained results are independent of the

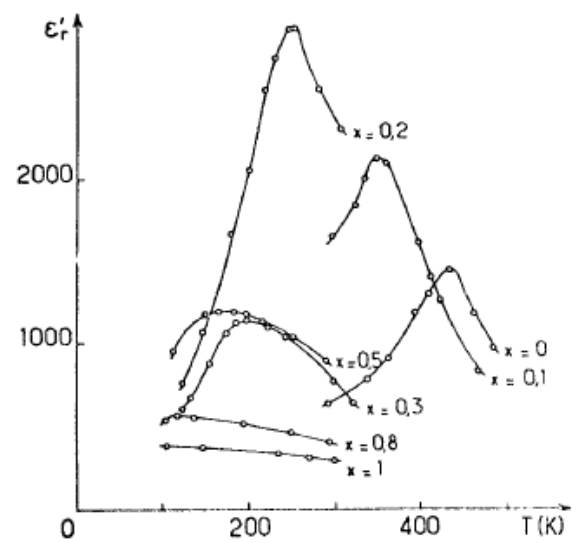

IIGURE 1 Variation of the permittivity with the temperature for the solid solution $\mathrm{Sr}_{2-x} \mathrm{~K}_{1+x} \mathrm{Nb}_{5} \mathrm{O}_{15-x} \mathrm{~F}_{x}$. various types of cationic substitutions, and depend only on the introduction of fluorine ions. Four solid solutions have been obtained.

Sintered samples have been prepared at $1200^{\circ} \mathrm{C}$ in platinum tubes sealed under dry oxygen. The dielectric measurements have demonstrated the existence of permittivity maxima. Figure 1 shows, for example, the obtained results in the case of the solid solution $\mathrm{Sr}_{2-x} \mathrm{~K}_{1+x} \mathrm{Nb}_{5} \mathrm{O}_{15-x} \mathrm{~F}_{x}$. We remark here that the temperature at which the maxima appear decreases, and also that the dielectric constant increases for a small amount of substitution.

Dielectric measurements at variable frequencies,
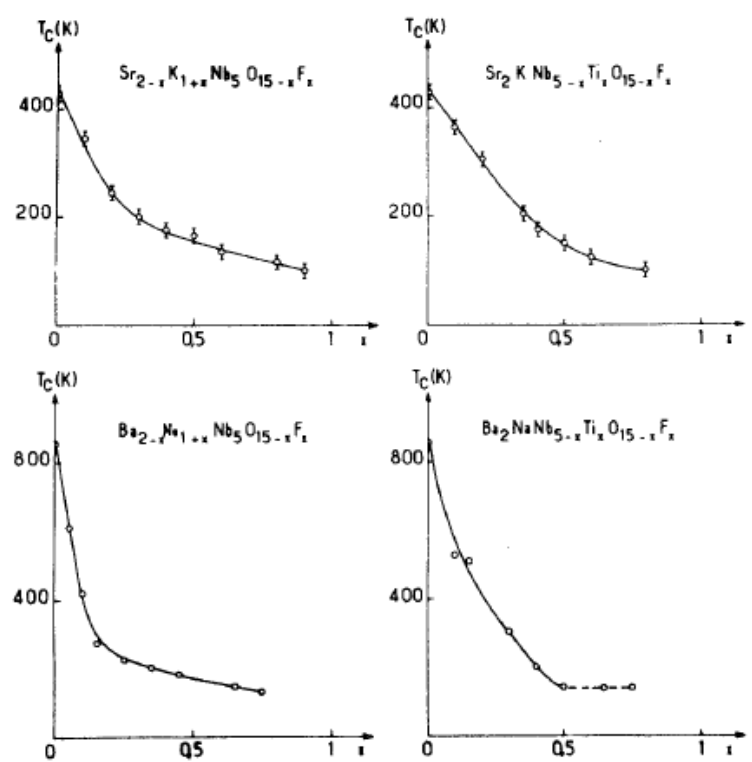

FIGURE 2 Variation of the Curie temperature with the composition. 


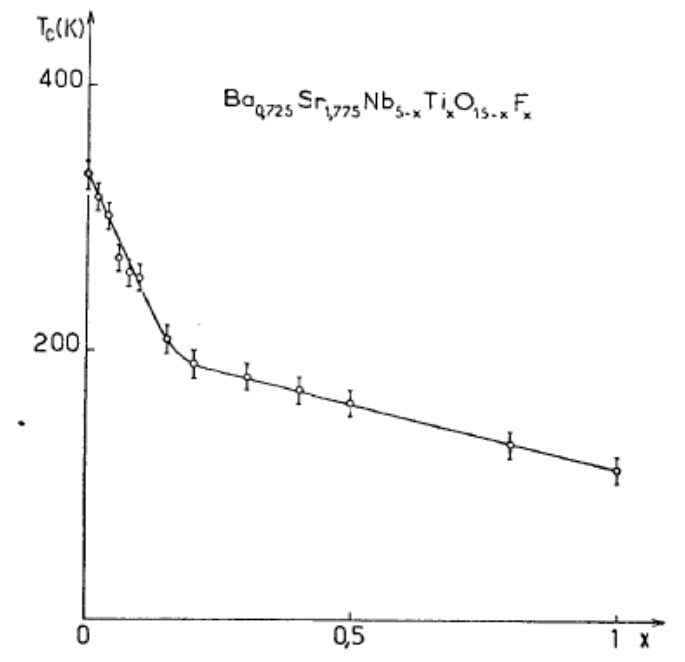

FIGURE 3 Variation of the Curie temperature with the composition.

as well as the appearance of hysteresis loops lead us to believe that we have a case of a ferroelectricparaelectric transition. The variation of Curie temperatures is represented in Figure 2. We observe in all cases a strong decrease of $T_{c}$ for small fluorine compositions.

When fluorine is substituted for oxygen, the $\mathrm{Nb}-\mathrm{X}(\mathrm{X}=\mathrm{O}, \mathrm{F})$ bonds become less covalents, and the anisotropy of the bonds decreases. Therefore the temperature required to give isotropic bonds (paraelectric phase) decreases.

We then proceeded to explain the increasing of the permittivity of sintered samples by studying the influence of the replacement of oxygen by fluorine simultaneously in the sintered samples as well as single crystals of $\mathrm{Ba}_{0.725} \mathrm{Sr}_{1.775} \mathrm{Nb}_{5} \mathrm{O}_{15}$ composition. The single crystals of the oxyfluoride were prepared by solid state diffusion from oxide crystals.

All the phases show a ferroelectric-paraelectric transition and a decrease of $T_{c}$ with the amount of fluorine (Figure 3). The sintering behaviour is favourably influenced by the presence of fluorine.

Similar results have also been found in other structural types: perovskite and pyrochlore..$^{8,9}$

In other words the replacement of oxygen by fluorine in ferroelectric sintered samples has been used to obtain dielectric materials with high performances. ${ }^{10}$

\section{REFERENCES}

1. B. A. Scott, E. A. Giess and D. F. O'Kane, Mat. Res. Bull. 4, 107 (1969)

2. L. G. Van Uitert, J. J. Rubin, W. H. Grodkiewicz and W. A. Bonner, Mat. Res. Bull. 4, 63 (1969).

3. E. A. Giess, B. A. Scott, G. Burns, D. F. O'Kane and A. Segmuller, J. Amer. ceram. Soc. 52, 276 (1969).

4. J. E. Geusic, H. J. Levinstein, S. Singh, R. C. Smith and L. G. Van Uitert, Appl. Phys. Letters 12, 306 (1968).

5. J. Ravez, J. P. Budin and P. Hagenmuller, J. Sol. State Chem. 5, 239 (1972)

6. J. Ravez, D. Tourneur, J. Grannec and P. Hagenmuller, Z. anorg. allg. Chem. 399, 34 (1973).

7. R. de Pape, C.R. Acad. Sc. 260, 4527 (1965).

8. G. Malabry, J. Ravez, J. L. Fourquet and R. de Pape, C.R. Acad. Sc. 277, 105 (1973).

9. J. Grannec, H. Baudry, J. Ravez and J. Portier, J. Sol. State Chem. 10, 66 (1974).

10. J. Claverie, G. Campet, J. Ravez, M. Perigord, J. Portier and P. Hagenmuller, C.R. Acad. Sc. 280, 801 (1975). 